\title{
Pastoralists and wildlife conservation in western China: collaborative management within protected areas on the Tibetan Plateau
}

Marc Foggin ${ }^{1,2,3^{*}}$

Correspondence: foggin@ plateauperspectives.org

${ }^{1}$ Plateau Perspectives, 200 Walnut Ave, St Lambert, Quebec J4P 2T1, Canada

${ }^{2}$ School of Anthropology and Conservation, University of Kent, Canterbury CT2 7NZ, UK

Full list of author information is

available at the end of the article

\section{Springer}

\begin{abstract}
Background: Pastoralists have long inhabited vast areas of western China, including the Tibetan Plateau region. Their traditional land use practices and cultural conservation ethic have helped to protect the natural resource base upon which they depend and the wildlife that co-exist with them in the grassland landscapes. However, in a rapidly changing socio-economic environment, including significant expansion of the protected area system and regional comprehensive development plans, local communities do not always have an evident voice in the conservation and development dialogues that closely affect their lives.

Results: With introduction and development of collaborative management - that is, a partnership between local communities, nature reserve authorities and other stakeholders - a landscape-level approach to conservation is now being modelled in Qinghai Province. Central to effective co-management are bi-directional relationships. There are also a wealth of direct and indirect services that may be provided by pastoralists under co-management, and in the compensation and payment options available to them in return for their critical services.

Conclusions: The contributions of pastoralists to wildlife conservation efforts are significant, but up to now insufficiently recognized. New insights regarding the relationship between pastoralists and wildlife conservation - including the potential role of community ecotourism, the development of local herders' cooperatives and of trust funds, and the need for greater clarity in local regulatory frameworks - are provided herein, with presentation of specific experiences and lessons learned from a project piloted in the headwaters of the Yangtze River over the past decade. A fuller, richer model of co-management is recommended.
\end{abstract}

Keywords: Co-management, Tibetan herders, Nature reserves, Western China, Landscape conservation

\section{Background}

\section{General background}

China is a vast country, covering an area nearly the size of Europe with a human population exceeding 1.3 billion people. What happens in this country affects the world whether in relation to rapid socio-economic development, climate change adaptation, approaches to conservation, or the balancing of needs and interests in a complex social and ecological environment. In addition, it is home both to an enormous variety of

(c) 2012 Foggin; licensee Springer. This is an Open Access article distributed under the terms of the Creative Commons Attribution License (http://creativecommons.org/licenses/by/2.0), which permits unrestricted use, distribution, and reproduction in any medium, provided the original work is properly cited. 
wildlife, much of which is now threatened or in danger of extinction, as well as to a diverse complement of peoples, cultures and livelihoods. Western China in particular is home to many ethnic minority groups - such as the Kazakh, Tibetan, Mongolian and other people - who, through their traditional pastoral production practices, have played a crucial role in the formation and maintenance of the vast grassland environments. The inhabitants have also valued and contributed to the conservation and sustainable use of wildlife over many centuries.

Facing the need to balance desired levels of economic development with environmental conservation and sustainability, China has established numerous nature reserves over the past several decades. More recently, it also has adopted a comprehensive plan for the development of its vast inland region, known as the Western Development Strategy (Chinese, xibu dakaifa). This far-reaching strategy includes major 'environmental' initiatives aimed at restoring or preserving the grasslands, which include more than $40 \%$ of China's land area, such as reducing livestock grazing pressure through temporary retirement of certain pasture areas (Chinese, tuimu huancao) and ecological resettlement schemes (Chinese, shengtai yimin) (Foggin 2008; Liu et al. 2005; Wang 2009; Xin 2008). Most nature reserves recently created in western China equally fall within the framework of the aforementioned development strategy, which began in 2000. According to international agreements such as the Convention on Biological Diversity, ratified by China in 1993, and also according to nature reserve purpose statements (e.g. Sanjiangyuan National Nature Reserve), the well-being of local people should be considered simultaneously with the biodiversity conservation and ecological protection mandates of formal protected areas. However, the respective roles and responsibilities of local people and of conservation authorities generally have not been clearly established, whether in terms of the specific activities that should be carried out in nature reserves, or the process of decision-making and other matters amongst stakeholders. Similar problems arise outside of protected areas too, where there is equal need for environmental protection and wildlife conservation - and where local herders could serve beneficially as partners in conservation, rather than deemed as a hindrance. Thus, new approaches for landscape-level conservation and pastoral development are needed (Harris 2008; Shen et al. 2011; Smith 2009).

The choice of land and wildlife management options adopted by government conservation authorities - whether inside or outside formal protected areas - stands not only to impact biodiversity conservation, but also to affect the lives, livelihoods and wellbeing of local communities. Such significant decisions generally are made for a variety of reasons and may include socio-political and development purposes as well as ecological motives (Breivik 2007; Harris 2009; Yeh 2005). Resource management policies and practices in western China have the additional complexity of having to interact with local ethnic minority groups and their long-standing land use patterns. If recognized and integrated in appropriate ways into protected area management plans and regional development plans, many traditional land use practices (and the local people's support and effective cooperation) may be harnessed for common agreed conservation goals (Banks et al. 2003; Wang 2009). The search for such forms of effective, fair collaboration with local communities in wildlife conservation - and more broadly, for sustainable pastoral development - is the basis and purpose of the project described here (Borrini-Feyerabend, Kothari et al. 2004a; Foggin and Bass 2010; Kothari 2008; Lynam et al. 2007). 


\section{Project background}

Working in the Tibetan Plateau region since 1998, Plateau Perspectives, a nongovernmental organization, has pioneered (in the local socio-political, geographic and environmental context) an integrated approach to environmental conservation and community development. This approach jointly addresses environmental and socioeconomic matters in light of observed and locally-perceived and -reported needs in the headwaters of the Yangtze River (see Foggin 2000, Foggin 2005b; Foggin et al. 2006; Foggin and Torrance-Foggin 2011). The focus has consistently been on 'community' needs (viz. several specific partner communities) rather than predetermined 'thematics', e.g. education, health, or conservation, which often are identified a priori as 'local priorities' by external agencies, such as non-governmental organizations. What has thus developed is a practical experience of 'co-management' (or 'collaborative management'; both terms are used synonymously). This is an approach to development that not only touches on environmental resource conservation, but also applies to nearly all aspects pertaining to the broad field of work known as sustainable development. This paper presents an overview of the local experience of co-management as well as local interactions between wildlife and pastoralists on the Tibetan Plateau (Figures 1 and 2), with an emphasis on the source area of the Yangtze River.

Primary funding for Plateau Perspectives' involvement in the piloting and development of this new and more collaborative approach to conservation and specifically to wildlife protection has come from the Norwegian Agency for Development Cooperation by way of Digni and HimalPartner, from the Ford Foundation, and from several private foundations and individual sponsors. Local partners have included county, township and village governments in southwest Qinghai Province; community associations and organizations; the Sanjiangyuan National Nature Reserve, administered under the provincial Forestry Department; and research colleagues from Qinghai Normal University, Qinghai College of Administration, Qinghai Academy of Social Sciences, Chinese Academy of Social Sciences, and elsewhere.

\section{Study area}

The Tibetan Plateau covers one-quarter of China's land area. It is the highest, most extensive mountain region in the world and comprises the headwaters of Asia's major rivers (the Yellow, Yangtze, Mekong, Salween and Brahmaputra rivers). The Tibetan Plateau is therefore known as the 'water tower of Asia' as well as 'the third pole' of the world (Foggin 2005a; Qiu 2008; Wang and Fu 2004; Yao et al. 2011). The traditional livelihood has been nomadic pastoralism, with seasonal movements between known pastures, and with societal structures (e.g. tribal and clan arrangements) that allowed for landscape-level natural resource management decisions (Foggin 2005b; Goldstein and Beall 1990; Miller 2000; Sheehy et al. 2006). Management flexibility and other riskaverse responses, for example in the face of natural disasters, also developed within the pastoral system of resource use (Næss 2004; Xu et al. 2008). With extensive and remote grassland, wetland and mountain landscapes, this high-altitude region is home not only to Tibetan pastoralists and their livestock, but also to a wide array of rare and endangered mammals including the Tibetan wild yak (Bos grunniens), Tibetan antelope (Pantholops hodgsonii), white-lipped deer (Przewalskium albirostris), wild ass 


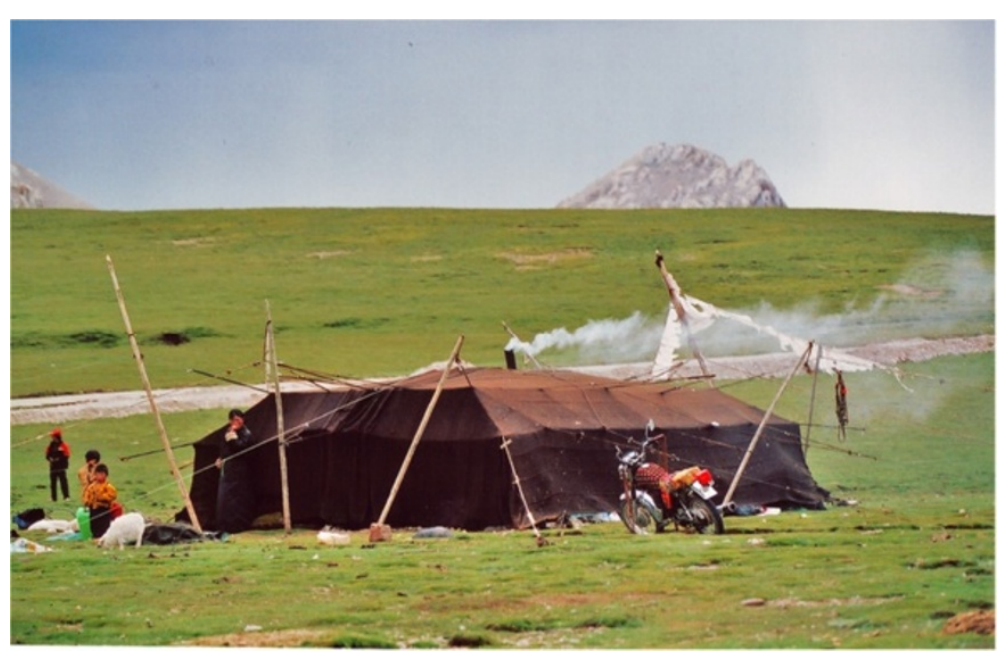

Figure 1 Tibetan tent and family.

(Equus kiang), argali (Ovis ammon), blue sheep (Pseudois nayaur), snow leopard (Uncia uncia), Pallas' cat (Felis manul), Tibetan fox (Vulpes ferrilata), brown bear (Ursus arctos), etc. Endangered and endemic birds of the plateau include black-necked crane (Grus nigricollis), bar-headed goose (Anser indicus), golden eagle (Aquila chrysaetos), lammergeier (Gypaetus barbatus), saker falcon (Falco cherrug), blue eared pheasant (Crossoptilon auritum), Tibetan rosefinch (Carpodacus roborowskii) and others.

\section{Pastoralists and wildlife conservation in western China}

\section{Recognizing community conserved areas (CCAs) on the Tibetan Plateau}

The wildlife of the Tibetan Plateau includes many endemic or near-endemic, threatened, or endangered species. Local pastoral communities in the headwaters of the Yangtze River, Qinghai Province, have long valued many of these species - for both personal and cultural reasons, for aesthetic reasons as well as traditional beliefs. In the words of one community leader: 'In Tibetan tradition, gold and silver are nutrients of the earth; in the same way, we see wildlife as decoration for the land. Without wildlife, the land becomes meaningless and we feel empty inside, we lose our connection to the land'. Some species also have religious significance to local pastoralists, such as the black-necked crane (Figure 3).

For such reasons, several communities partnered together from the late 1990s, first to establish a local non-governmental organization - the Upper Yangtze Conservation and Development Organization - and second, to delineate several community conserved areas (CCAs) in the region (see Borrini-Feyerabend 1996; Borrini-Feyerabend et al. 2004b). The hope and plan always has been that 'conservation' and 'development' would proceed together, bringing forth real-life improvements for the community as some members participated, on behalf of the whole community, in active conservation work - organized through membership in environmental teams, e.g. the snow leopard monitoring team, garbage disposal team, etc. With a different focal species (or habitat) selected by each community, when considered together, these CCAs formed a wide network of local protected areas. In effect, the pastoralists of Suojia township, in western Zhiduo County, Yushu Tibetan Autonomous Prefecture, thus created a people-centred, 


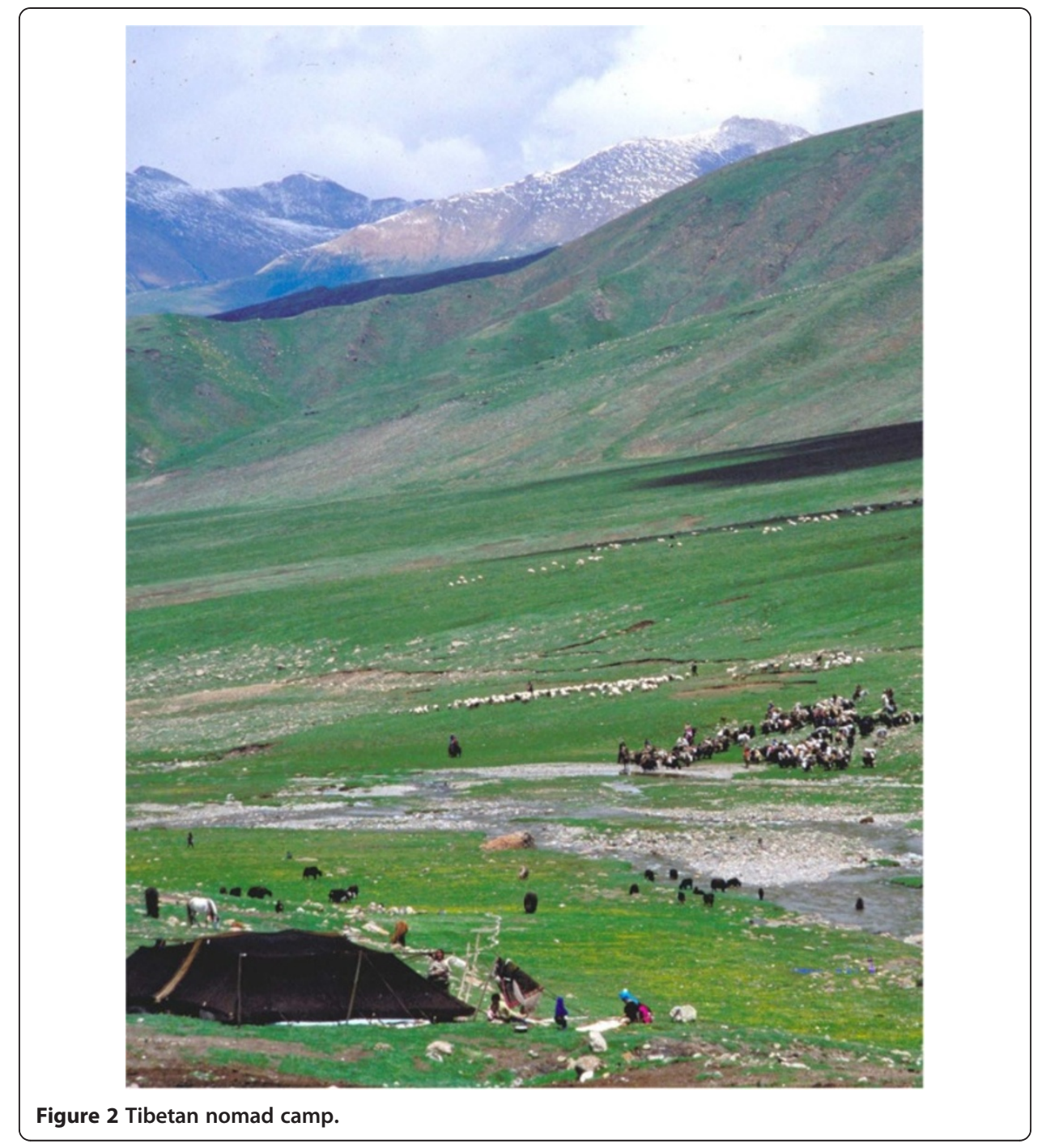

multiple-use, regional conservation and land use management plan (Figure 4). From the outset, they also hoped that their efforts to protect the local wildlife would be recognized - and possibly compensated - by higher level government authorities or through environment-friendly economic ventures such as community ecotourism (Li and Han 2001; Cho 2011). The CCAs have focused specifically on the snow leopard, Tibetan antelope (chiru), Tibetan wild ass (kiang), black-necked crane, and on a locally significant wetland habitat. Later, another CCA focused on wild yak was also established.

While the CCAs were initially selected in large part by the communities themselves, with assistance and support from the Upper Yangtze Conservation and Development Organization and Plateau Perspectives, the national and global significance of the region's biodiversity was recognized more widely when a new protected area, the Sanjiangyuan National Nature Reserve (SNNR), was established in 2003. After a few years, the local communities' sustained efforts to conserve selected focal species were recognized more formally with the launch of the 'Sanjiangyuan Co-management and Biodiversity Protection Project' (in Chinese, originally known as the Yicun Yidian project) in November 2007 (Lhamo and Tsering 2008). By way of these original CCAs, 


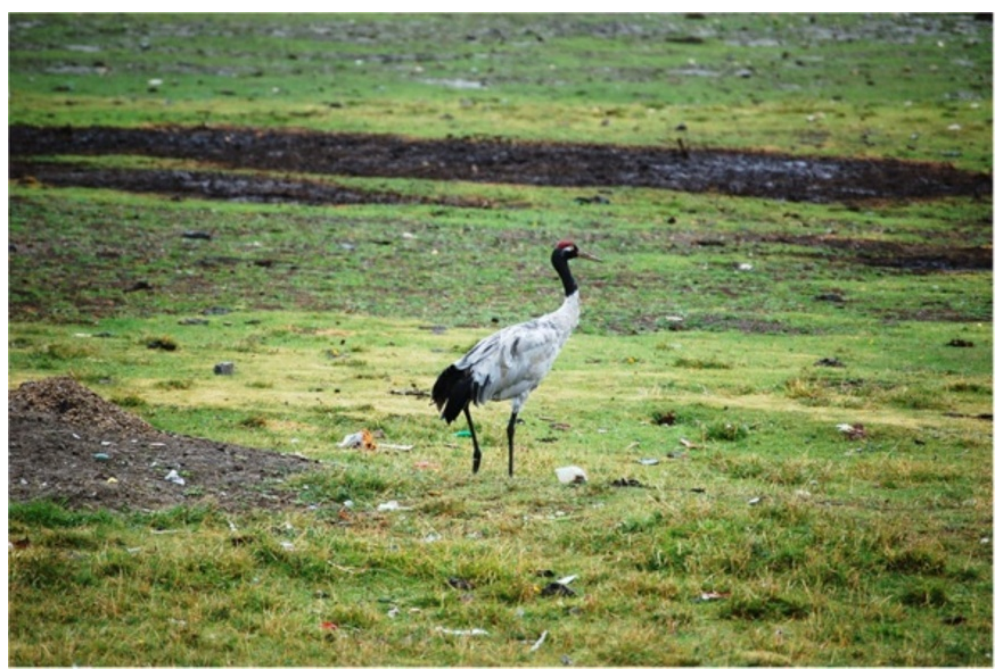

Figure 3 Black-necked crane.

collaborative forms of wildlife conservation and resource management have thus been integrated into the modus operandi of the SNNR's Suojia station, one of the first operational field stations in one of the largest nature reserves in the world (SNNR's total area is $152,300 \mathrm{~km}^{2}$ ) (Figure 5). The SNNR was officially established with dual goals to protect the Tibetan Plateau ecosystem, with an emphasis on alpine swamp meadow and natural habitat of the region's unique wildlife, and to promote sustainable economic development in the region (Foggin 2005a). More detailed information about the nature reserve is provided by Lhamo and Tsering (2008) and Foggin (2005a).

Amongst the endangered wildlife now being monitored and protected in collaboration with local people and communities, the snow leopard is the rarest on a global

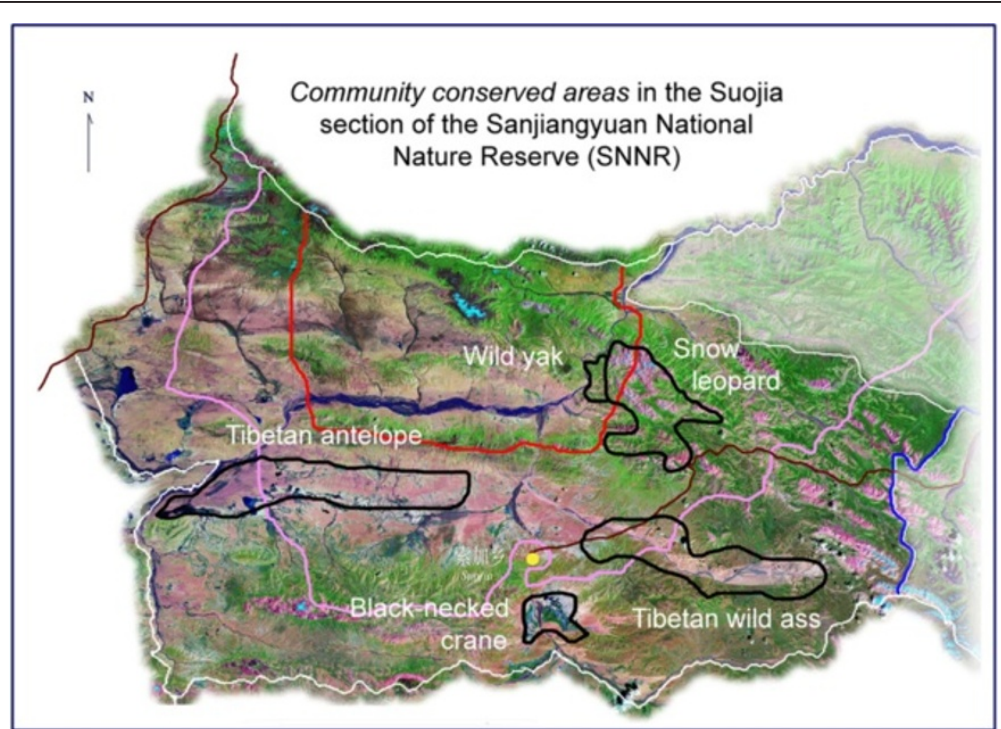

Figure 4 Original CCAs in the Suojia area of the Sanjiangyuan National Nature Reserve. The areas formed a basis for the development of a multiple-use regional conservation plan in the heart of the Tibetan Plateau. 


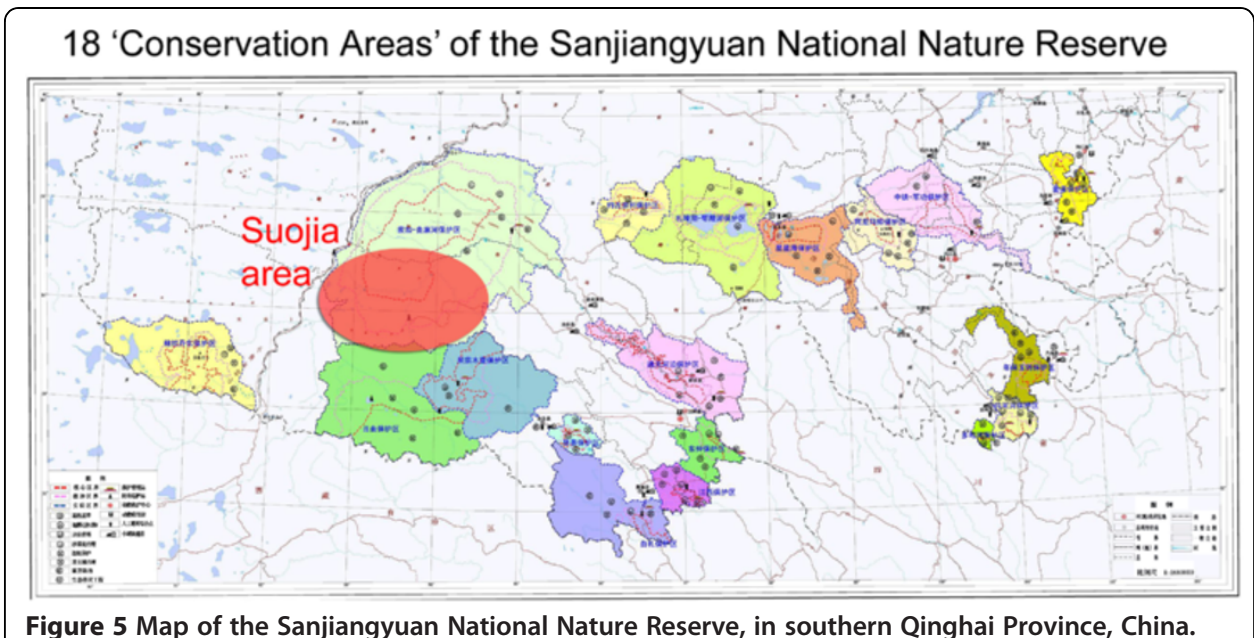

Figure 5 Map of the Sanjiangyuan National Nature Reserve, in southern Qinghai Province, China.

scale (estimated population, between 4,080 and 6,590 individuals; Jackson et al. 2008) yet with significant local numbers. Based on camera trap observations (which are being used to complement herders' direct observations), Suojia appears to be a 'hotspot' in terms of snow leopard density, with seven to nine individuals identified, and more likely to be present (based on other signs and herders' observations), in an area approximately $150 \mathrm{~km}^{2}$ (Plateau Perspectives 2011a). Tibetan antelope are also endangered, as well as endemic to the Tibetan Plateau, with a current population estimated at less than 150,000 individuals; they used to number in the millions (Mallon 2008; Schaller 1998). Wild yak numbers are estimated at around 15,000 individuals (Harris and Leslie 2008). Both Tibetan antelope and wild yak have local populations, possibly resident, in the Suojia area. Black-necked crane also are relatively abundant in the project area, where CCAs were created in 1998, yet their total number worldwide is only approximately 11,000 individuals (BirdLife International 2012). Finally, while Tibetan wild ass are more numerous - between 60,000 and 70,000 individuals (Shah et al. 2008) - their biology remains insufficiently known, particularly their seasonal movements and distribution patterns (Schaller 1998; Shah 2002). The snow leopard (Figure 6) and wild ass (Figure 7) both also present some conflict for local pastoralists, through depredation and competition with livestock; thus, further monitoring and study of these nearendemic species of the Tibetan Plateau is warranted, in order to develop appropriate management responses. Other species that may harm or damage local people's livelihoods include the Tibetan brown bear and the wolf.

Historically, the primary threat to most wildlife was illegal hunting. With strengthened wildlife laws as well as increased environmental awareness, however, there is now greater threat, locally and across China, due to habitat modification and degradation (e.g. road construction, modified livestock grazing patterns) and human disturbance (e.g. unplanned tourism, new urban developments). In light of these factors, wildlife conservation in pastoral areas has been promoted through this project in two significant ways: first, through the introduction of collaborative management as a new approach to conservation (and as elaboration of precursor CCAs); and second, through initial development of community-based ecotourism ventures, which - if carried out according to agreed international principles of ecotourism (TIES 2012) - can promote 


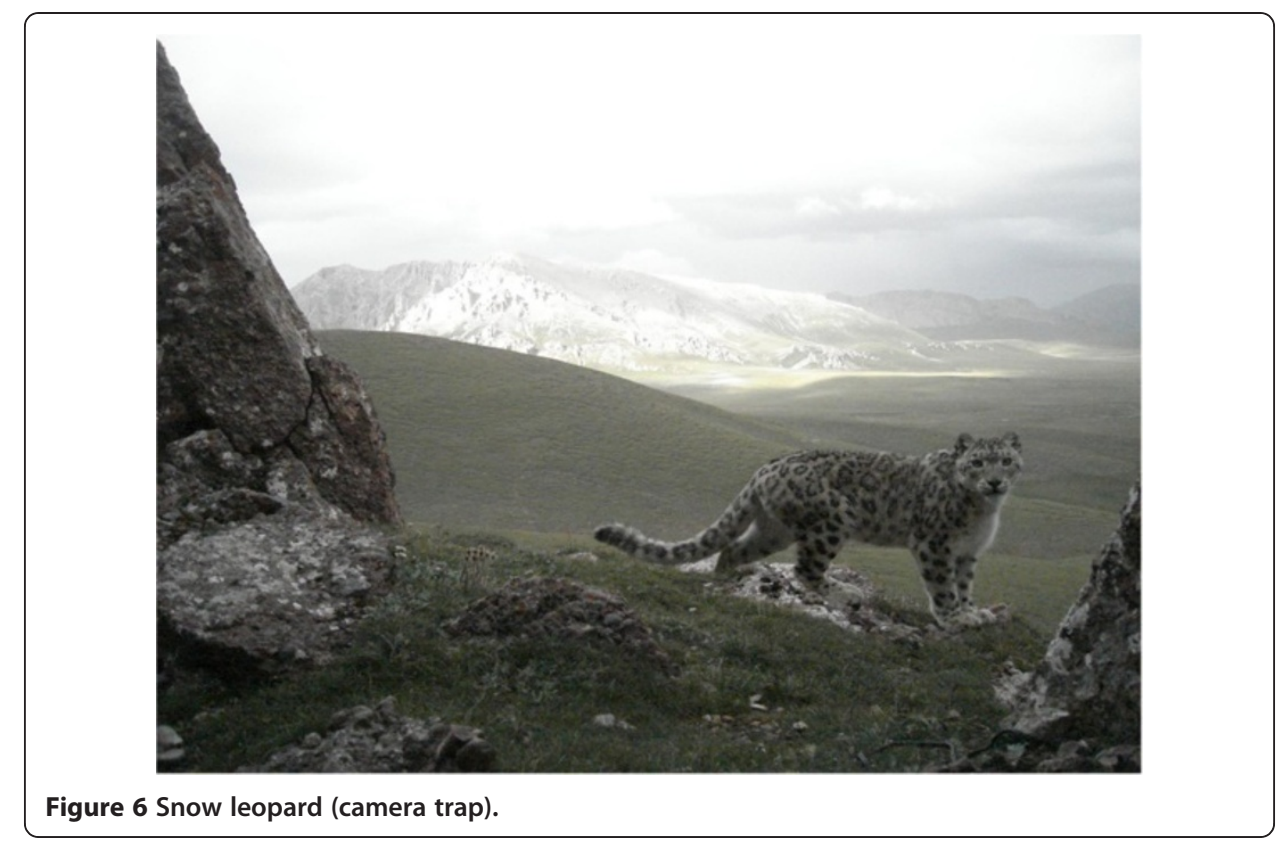

socio-economic development and conservation agendas, simultaneously. The three main partners in the work described herein have been national conservation authorities, in the form of SNNR and its Suojia field station, working together with Plateau Perspectives and Tibetan pastoralist communities - working under the auspices of the Yicun Yidian (co-management) project.

\section{Main activities undertaken by Tibetan pastoralists as co-managers}

Working in concert with SNNR authorities, local community members have now served for several years as de facto nature reserve wardens. Their central roles include monitoring wildlife populations, carrying out anti-poaching patrols and raising environmental

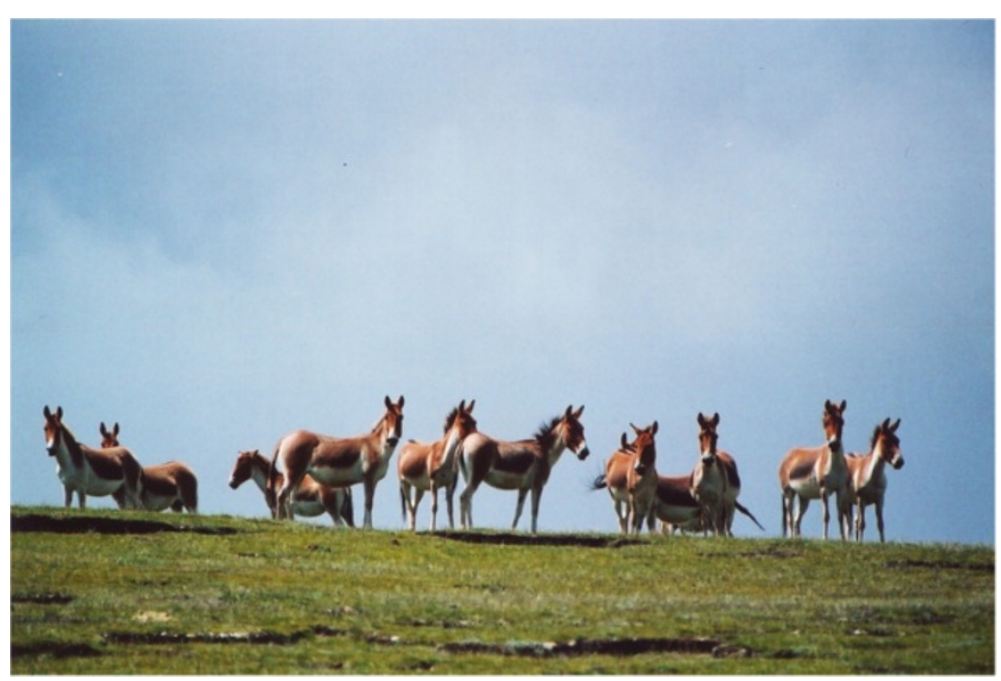

Figure 7 Tibetan wild ass. 
awareness amongst the general public. By way of example, in the case of Muqu village, the community has chosen to focus its co-management efforts on the monitoring and conservation of snow leopard. In early years, from circa 1998, simple data collection forms deemed suitable for non-literate or semi-literate participants were used (Figure 8) to document the presence and the relative abundance of selected wildlife species. Following the discussion in October 2007 between SNNR staff and local wardens about community management in the region (Figure 9), a detailed management structure was agreed amongst all the project partners outlining data collection methodology, timetables and reporting mechanisms. All members of the snow leopard team (i.e. local wardens) agreed where they would conduct wildlife transects (Figure 10), when they would carry out the transect surveys (specific dates, four times per year), and what information to collect (including both direct and indirect observations of snow leopard including scrapes, scat and

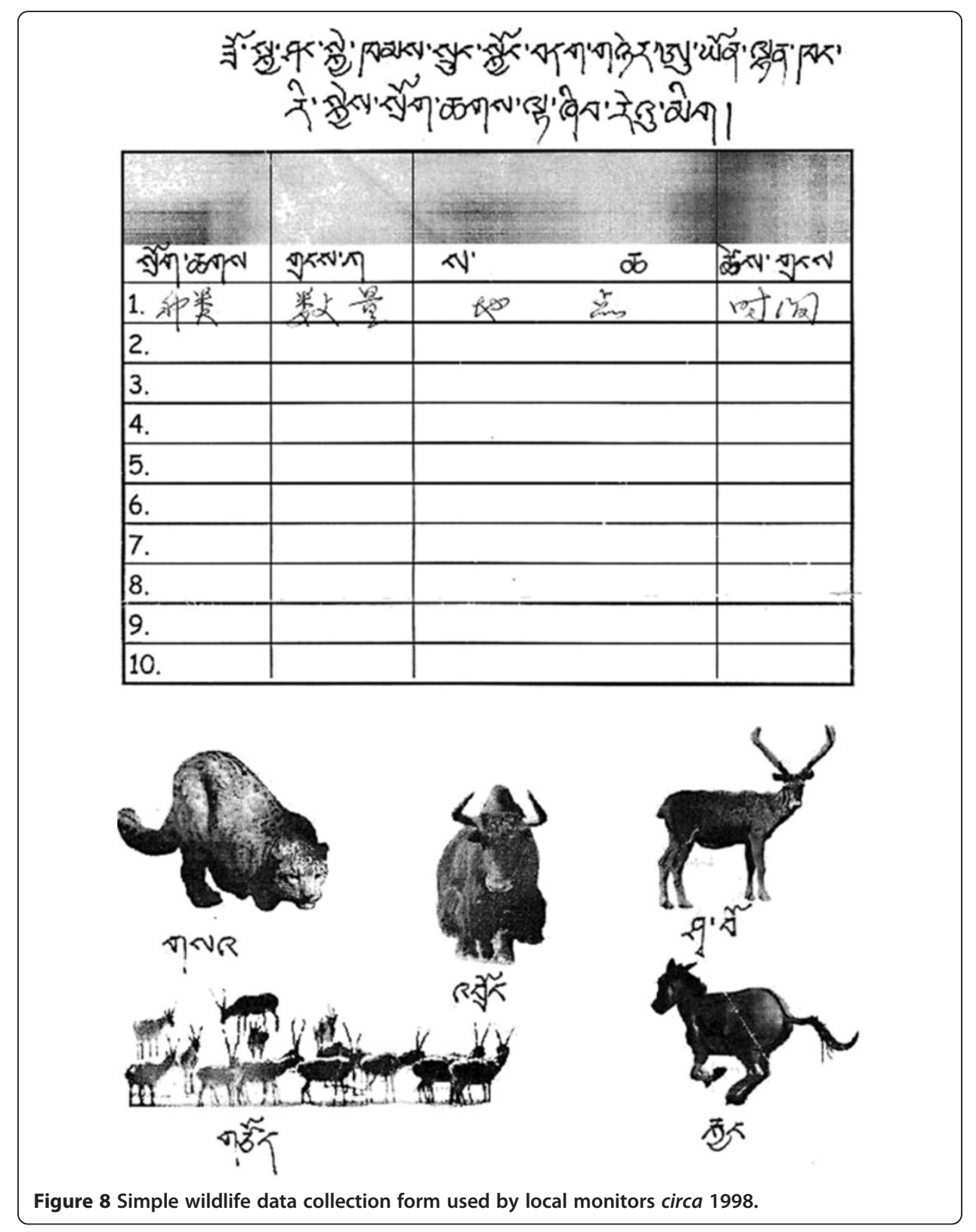




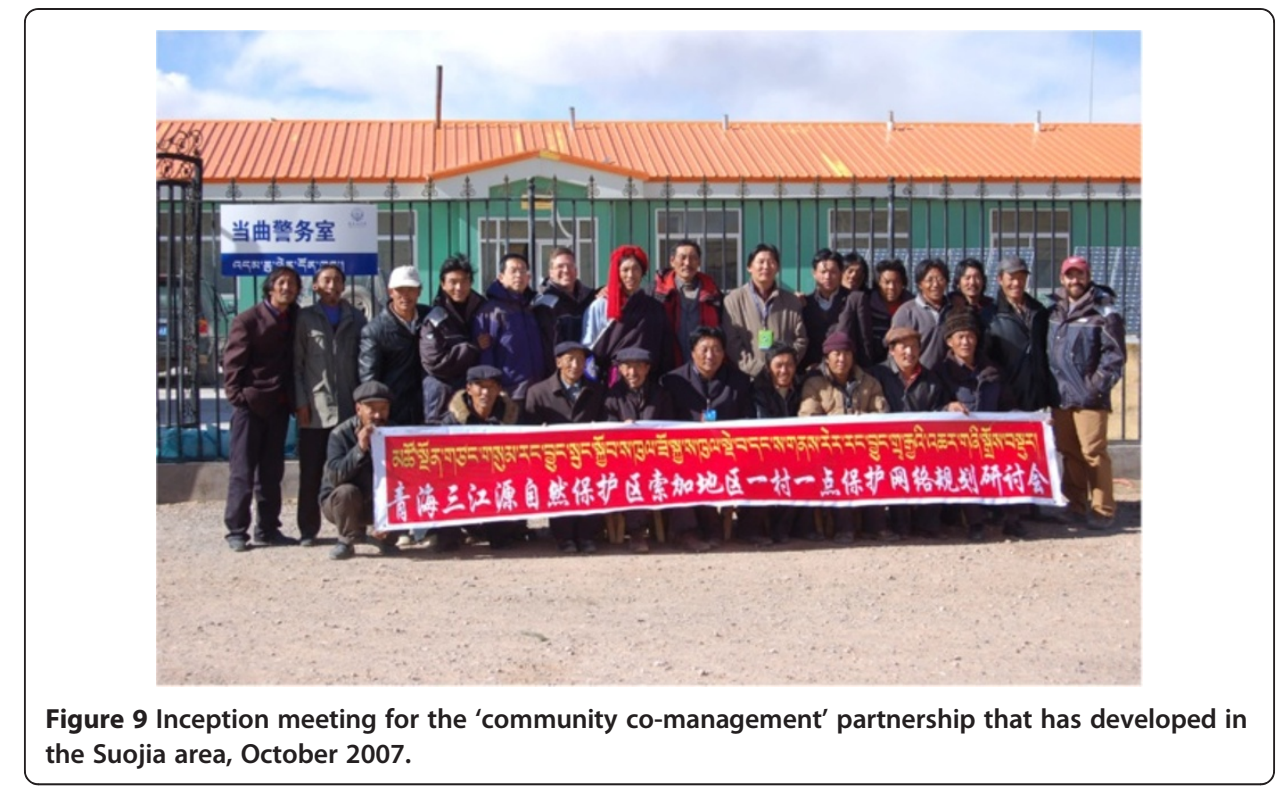

other sign, and indicators of prey species). As such information is gathered systematically over time (i.e. repeated measures), a trend analysis can be made for the snow leopard population in the area, which can help to inform and to direct management actions by the community and nature reserve authorities. As this approach to data collection (and other aspects of co-management) is refined in the future, with further training and capacity building, more of the wildlife data analysis could equally be done at site level - which

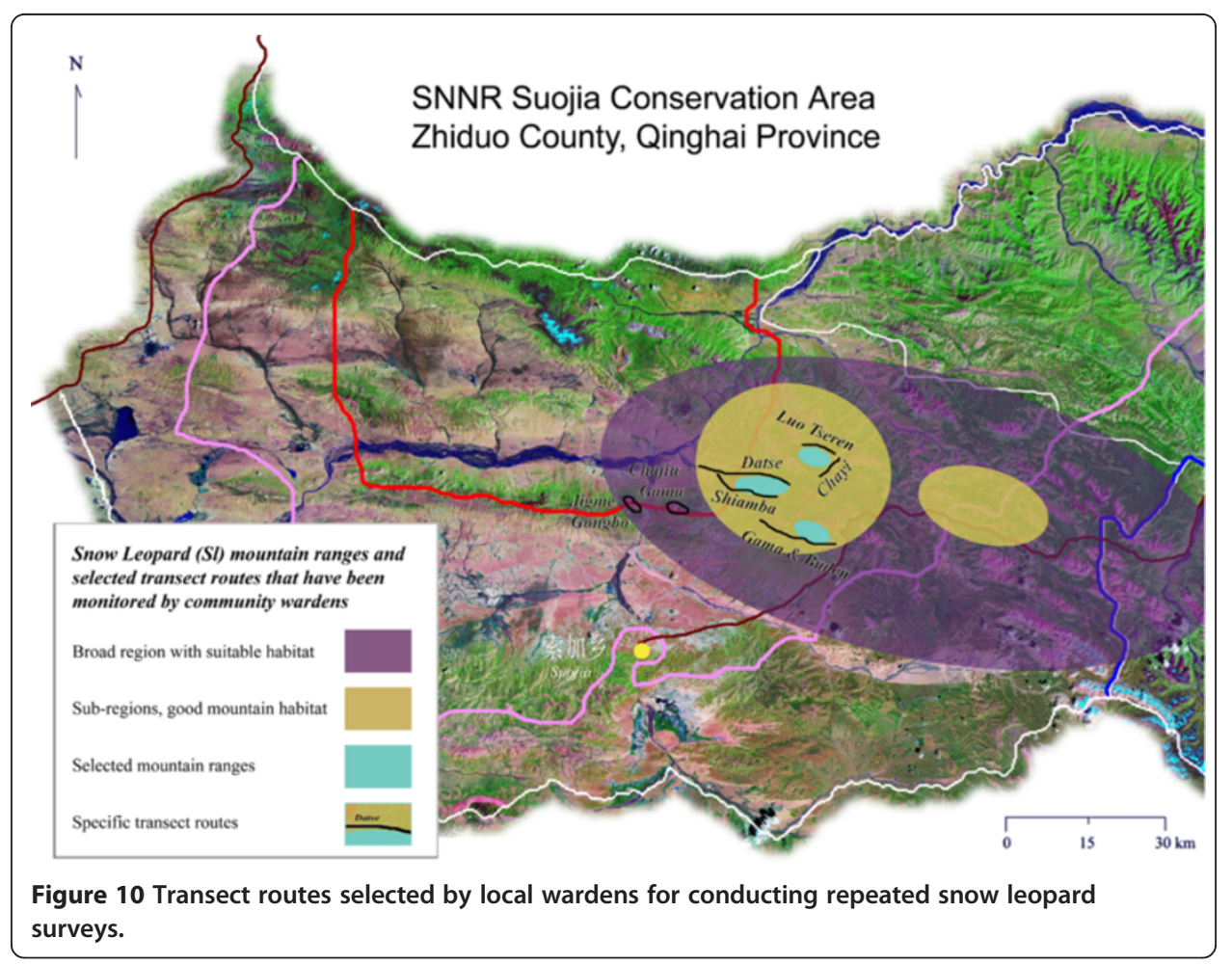


would help close some of the gaps that still exist between data collection, on one hand, and management decisions (conservation actions), on the other hand.

Based on monitoring efforts from 2008 to 2010, 22 snow leopard sightings were documented by the local monitors. In addition, the following also were documented: Tibetan wild ass (kiang), wild yak, Tibetan antelope (chiru), blue sheep, argali, Tibetan gazelle, white-lipped deer, Pallas' cat, Tibetan brown bear, Tibetan hare, black-necked crane, bar-headed goose, ruddy shelduck, brown-headed gull and Pallas' gull.

In addition to transect-based surveys, a camera trapping scheme also was established in December 2010, which aimed to confirm or complement the snow leopard data gathered through community wardens' observations. From photo analysis (Figure 11), it was found that seven to nine individual leopards are present in approximately 150 $\mathrm{km}^{2}$, based on 21 different photographic events and more than 100 photographs. The additional information thus gained is complementary to that obtained through transect surveys; both should be continued. In addition, more training would help ensure that wildlife data is gathered more systematically by local monitors. Additional field equipment also is recommended for wardens and field station managers, to help the SNNR and Tibetan pastoral communities further develop the quality of their innovative conservation co-management partnership (Foggin 2011a; Plateau Perspectives 2011b).

The main value of such snow leopard data is for monitoring purposes - in light of current and expected development changes in the future, e.g. road construction projects, increased disturbance with tourism development, etc. With baseline information now available, monitoring of potential impacts can begin, which could beneficially inform and guide natural resource and wildlife management, and development plans, in the future.

\section{Support needed for the development of 'community ecotourism'}

As local communities seek to protect the environment, with local as well as regional benefit, they also seek to develop their economic opportunities. Partnerships imply mutual understanding and assistance, and as such, co-management arrangements should

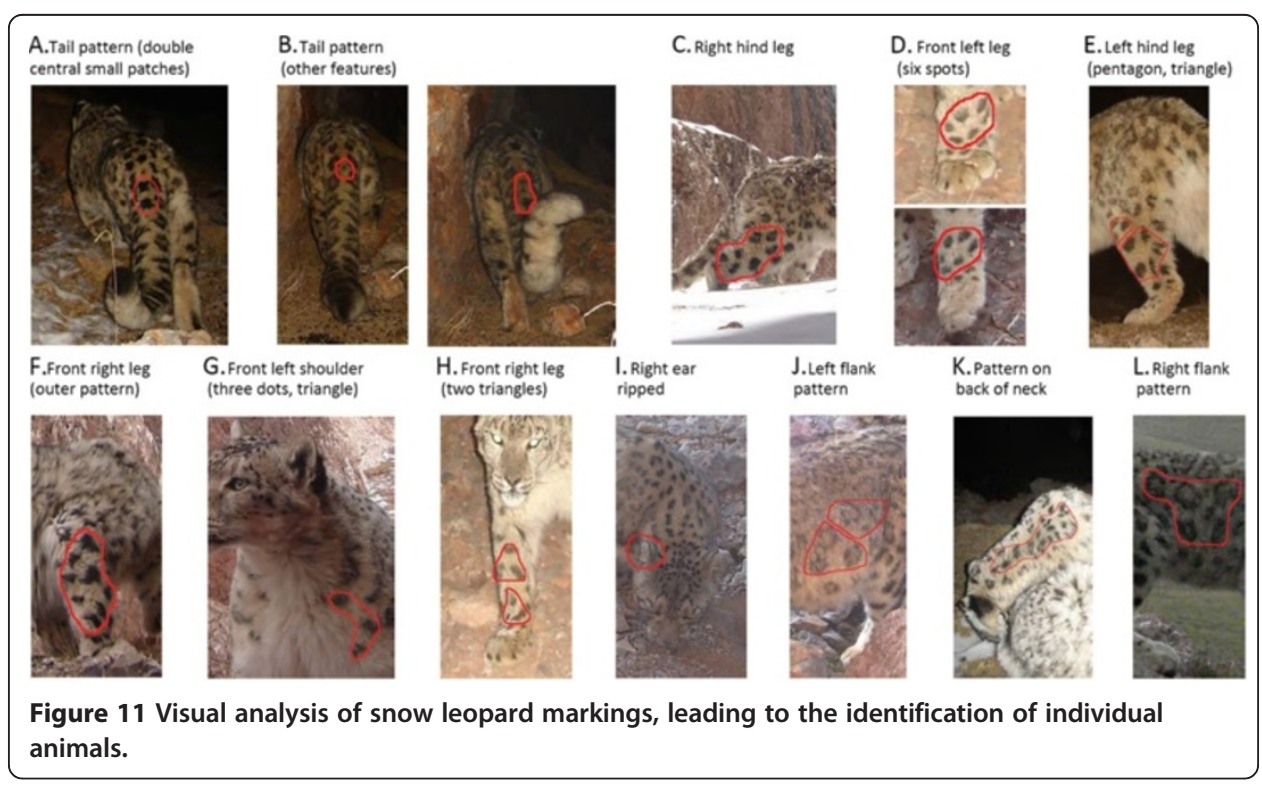


equally be supportive of local needs and aspirations (Reed 2008; Schlick 2011; Yang 2011). In addition, from a pragmatic perspective, when local people and communities are paid or compensated for services - whether for direct services, e.g. wildlife monitoring, anti-poaching patrols, etc., or indirect services, e.g. land use practices that maintain ecological functions - there is also need for financing structures at the community level that are equitable, transparent and practical for local socio-economic development.

In remote, rural areas of the Tibetan Plateau, community ecotourism is now being promoted, supported in large part by regional government policy. Yet, protected area planning is still needed with regard to such ventures - to help guide and facilitate, and sometimes also to constrain or limit, such activities. Greater clarity is needed in particular regarding the types and extent of community tourism deemed allowable within protected areas (Li and Han 2001; Wang et al. 2009; 2012). It would also be beneficial if the many and varied tourism-related stakeholders could agree on a common definition of ecotourism (which is significantly different from nature-based tourism; Plateau Perspectives 2011b), and that other sectors of government such as poverty alleviation bureaus would recognize the role that local people and communities may play in the tourism sector (cf. tourism for development, or ecotourism by communities).

Ecotourism is related to, yet at its core quite different from, nature-based tourism. Ecotourism is not simply travel through areas of exceptional natural beauty, even if such travels are considered to be responsible and sustainable - that is nature tourism. Most significantly, by definition, ecotourism must contribute directly to local communities' well-being and include tangible conservation action (not only 'do no harm') - as explained by The International Ecotourism Society, which provides a list of the key principles of ecotourism and other useful guidelines (TIES 2012).

A specific case study is that of the Kegawa Herders Cooperative, established in 2009 with many of the above considerations in mind. The cooperative is now comprised of around 30 families in Lari Village, in Yushu Tibetan Autonomous Prefecture, Qinghai Province. Its regular operations are overseen by an executive committee of seven people, and major decisions are made by vote during its annual general meeting. Cooperative members have invested in differing amounts, thus building up the cooperative's core fund, but each member has an equal, single vote. Several business ventures are currently being tried including a small shop in the county town, community-based tourism, valueadding for livestock products and handicraft development.

Community trust funds are another innovative way that could be used to fund community-benefit activities, or from which loans can be made to individual community members. Such a trust fund approach equally could be used to receive and manage payments made to communities in the context of co-management projects, e.g. for wildlife conservation initiatives, profits from community ecotourism ventures, etc. Such trust funds are particularly effective in remote locations with scattered populations, such as Tibetan herders with traditions of community-level action that aim to manage common property resources. Several study tours to Mongolia and to Sichuan and Yunnan provinces in China already have been undertaken, in order to learn more about the detailed functioning of such trust funds and herders' cooperatives, prior to their trial establishment in the Sanjiangyuan region.

Whether local governance is enhanced through herders' cooperatives, trust funds, or other approaches, alleviation of poverty can be strengthened when local people are 
enabled (financially and otherwise; Nabavi 2009) to develop small- and medium-sized initiatives of their own creation. For this purpose, several community discussions have recently been initiated with a focus on the development of community tourism (which can couple conservation and economic needs), several eco-tours have been piloted, and an 'ecotourism network' has been proposed in the context of a strategic discussion and planning workshop co-hosted by Qinghai Normal University and Plateau Perspectives. Community-based ecotourism now is also being integrated into local nature reserve plans, initially at the level of one of the reserve's field stations. This type of reciprocal support under the umbrella of collaborative management, with conservation efforts at community level coupled with support for appropriate socio-economic development opportunities (such as community ecotourism), may provide the foundation necessary for long-term relationships to develop and genuine partnerships to be established.

\section{Collaborative management: filling in all the right boxes}

Collaborative management of natural resources, or indeed co-management for any agreed purpose, is a complex enterprise, but an approach that, if executed properly, can bring benefits at multiple levels (Chen et al. 2012; Liu et al. 2011). As summarized by Vernooy (2011), co-management is 'a form of adaptive management that builds community resilience.' The strength of co-management lies in the mutual reinforcement that all the component parts bring to bear on each other. Co-management thus is more than a two-way highway, with payments given for services rendered. It comprises a much broader network of relationships, of supporting actions, of mutual understanding - that, all together, can lead toward agreed common goals.

If understood from a minimalist perspective, co-management may not incorporate all the relationships, interactions and exchanges that are important for sustainability or wildlife conservation. With regard to community involvement, for example, there is a danger that the partnership could grant local people no more than a right to continue living on the land, in exchange for their services as community wardens. Valuable as that may be (i.e. compared to resettlement and fundamental changes of livelihood, as are being promoted by government policies that promote 'ecological migration'; Foggin 2011b; Foggin and Torrance-Foggin 2011; Foggin and Phillips forthcoming), it is still possible to have much greater levels of cooperation amongst stakeholders. In particular, the question arises of how local people's labour should be recompensed - whether for the maintenance of critical ecological services ( $c f$. sustainable land use), the provision of services rendered (e.g. contributions as wildlife monitors) or opportunities lost due to conservation-based restrictions (e.g. required reductions in livestock numbers).

Co-management approaches also should take into account the need for funding transfer mechanisms, including the development of adequate financing and management structures at community level for receipt and oversight of payments. Enhanced clarity in terms of government regulations - e.g. regarding the establishment and operation of community cooperatives and community trust funds, and the scope for development of community ecotourism in protected areas - also would assist in the development of effective partnerships between pastoral communities and protected areas. Such a broader perspective on co-management, which clearly encompasses the varied roles, relationships and responsibilities that pertain to local herders and 
conservation authorities, is presented graphically in Figure 12 and in tabular form in Table 1. In short, in a more fully developed co-management model, not only would local people contribute to conservation authorities' need for field-based monitoring of wildlife populations, for anti-poaching support, etc., there would also be, in the opposite direction, support for local communities' socio-economic development endeavours, as long as these remain clearly within the parameters of the environmental goals of the region (whether inside or outside of protected areas). Thus, when a social-ecological system such as the Tibetan grassland environment is overlaid with a 'co-management model' (Figure 12), this model should include three main levels, each with complementary halves (see Table 1). First, for all direct services rendered by community members, appropriate payments should be made. Second, for indirect services such as the maintenance of proper ecosystem functions (whether this be based on continuation of traditional practices, or the adoption of new sustainable land management practices), adequate payments for these ecosystem services should be made, or for opportunities lost ( $c f$. eco-compensation). Third, the government should provide supporting and enabling environments for environmentally sound socio-economic development to take place in areas of ecological interest. Such support may include enhanced clarity regarding strategic opportunities and legislation affecting local development, e.g. community ecotourism in nature reserves, and the creation of more space for community-based financial mechanisms and structures, e.g. community cooperatives and trust funds.

While not all of the 'boxes' (i.e. topics or issues) in Table 1 have yet been directly addressed through co-management in the Tibetan Plateau region, significant progress

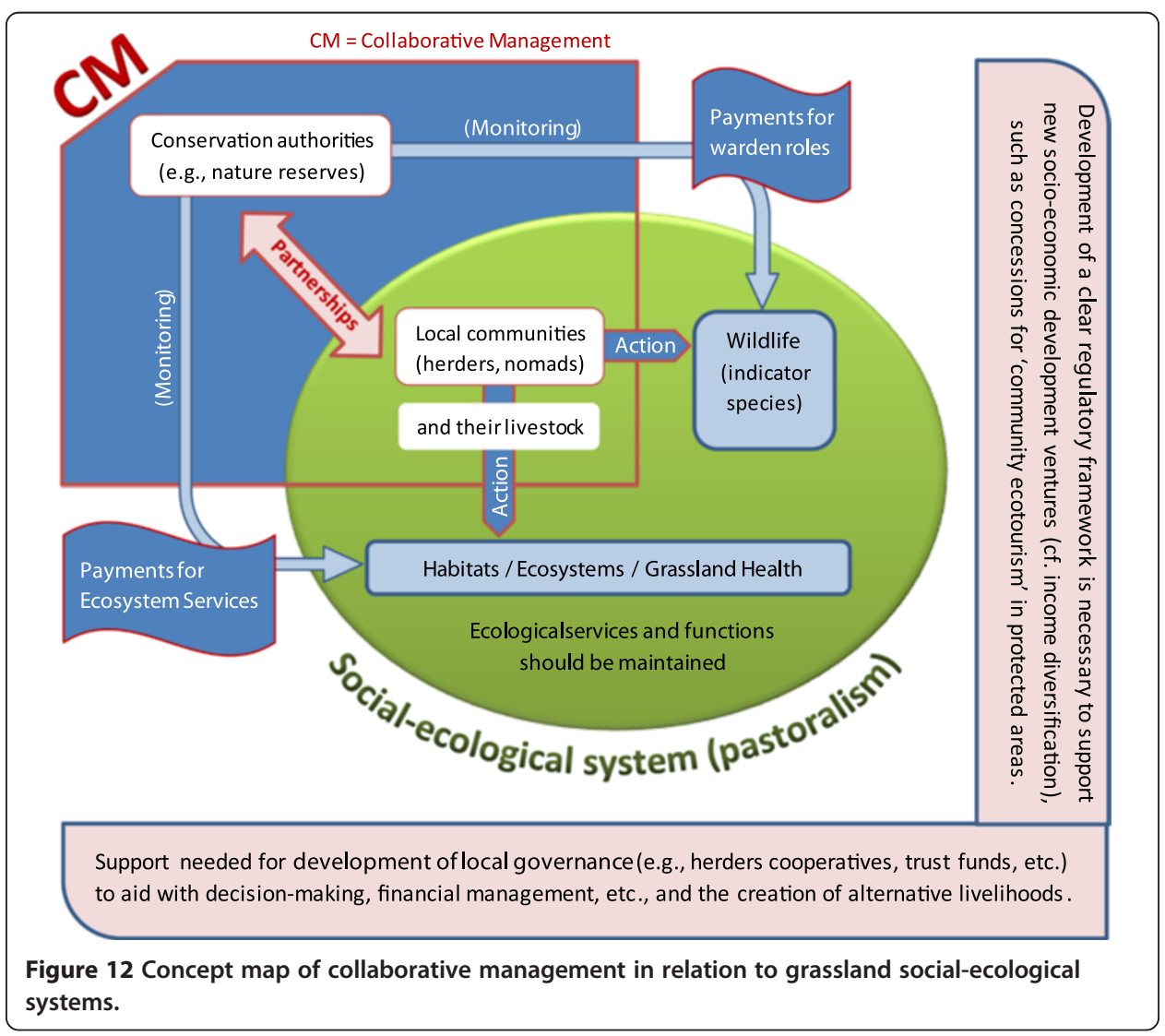


Table 1 Services provided and benefits received by the partners in an expanded comanagement model

\begin{tabular}{|c|c|c|}
\hline & $\begin{array}{l}\text { Actions taken by communities; } \\
\text { of benefit to conservation authorities }\end{array}$ & $\begin{array}{l}\text { Actions taken by conservation authorities; } \\
\text { of benefit to communities }\end{array}$ \\
\hline \multirow[t]{2}{*}{$\begin{array}{l}\text { Direct } \\
\text { contributions }\end{array}$} & $\begin{array}{l}\text { Wildlife monitoring, anti-poaching patrols, } \\
\text { environmental awareness-raising activities, etc. }\end{array}$ & Payment for services rendered \\
\hline & $\begin{array}{l}\text { Sustainable land use, cf. maintenance of } \\
\text { ecosystem services/function }\end{array}$ & $\begin{array}{l}\text { Payment for Ecosystem Services or various } \\
\text { forms of eco-compensation, to be delivered } \\
\text { directly to local communities }\end{array}$ \\
\hline $\begin{array}{l}\text { Supportive } \\
\text { actions }\end{array}$ & $\begin{array}{l}\text { Local governance - development of local } \\
\text { decision-making and financing tools or } \\
\text { mechanisms (e.g. herders' cooperatives, trust } \\
\text { funds, etc.), which may assist in the } \\
\text { development of new economic ventures } \\
\text { (e.g. community-based ecotourism) }\end{array}$ & $\begin{array}{l}\text { Regulatory - development of a clear legal } \\
\text { framework (e.g. for community-based } \\
\text { ecotourism in protected areas, public-private } \\
\text { partnerships, etc.), which could assist in the } \\
\text { creation of new alternative livelihood options }\end{array}$ \\
\hline
\end{tabular}

has still been made. More attention is needed, though, particularly with regard to ecocompensation schemes or the delivery of payments for ecosystem services, which have not yet been viewed through the lens of co-management. Fortunately, some of this oversight soon will be redressed through a new large project focused on collaborative management, co-funded by the Government of Qinghai Province and the Global Environment Facility, entitled Enhancing the effectiveness of protected areas for biodiversity conservation in Qinghai Province. It is hoped that this large-scale project may provide the encouragement and technical inputs necessary to more comprehensively fill in all the right boxes - thus developing and then presenting and extending more widely a balanced and more sustainable model of collaborative management in the grassland areas of western China.

\section{Conclusions: The road ahead}

A fine road lies ahead - both a good road and a delicate, challenging road with human dimensions!

Based on direct experiences spanning more than a decade in the Tibetan Plateau region, both observing and assisting community-based wildlife conservation initiatives, the most promising approach to engage local support for conservation (or conversely, to serve and support community conservation initiatives) appears to be that which is now often referred to as 'collaborative management'. Such an approach may take on a variety of forms or names, but the common denominator is that genuine partnerships are necessary. On this basis, and seeking to create an enabling environment in which Tibetan nomadic pastoral livelihoods may be maintained while simultaneously improving wildlife conservation outcomes, a co-management framework was proposed to the Sanjiangyuan National Nature Reserve in 2005 (Foggin 2005a), an approach that has since been piloted and developed in the Suojia area up to the present.

Collaborative management has been defined as 'a partnership by which various stakeholders agree on sharing among themselves the management functions, rights and responsibilities for a territory or set of resources under protected status' (BorriniFeyerabend 1996). Real collaboration amongst stakeholders is crucial for successful resource management, yet groups with divergent interests must work together. Such partnership involves understanding complex systems with both human and natural 
components (Blumenthal and Jannink 2000). However, when a diverse array of parties agrees to work together, they also bring with them different capacities - i.e. knowledge, skills, resources, etc. - that can be brought together for mutual advantage (Ross and Powell 2008).

The next critical question is then, In what specific matters should there be collaboration, if the end-goal is wildlife conservation? More than simply asking local people to serve as wildlife monitors (or wardens), whether for free, in exchange for a right to stay on the land, or for formal payment - 'co-management' also should consider other forms of exchanges and contributions toward conservation goals, including payments for (maintenance of) ecosystem services, or eco-compensation schemes, in exchange for sustainable land use and wildlife conservation in pastoral community areas (see Table 1). Experiences in Mongolia over the last decade may provide additional insights into the development of co-management, with both environmental and socio-economic benefits arising at local to regional levels (Schmidt 2006; Ykhanbai et al. 2004). While Vernooy (2011) has properly identified local people as the key social units in co-management endeavours, still there is necessity also to involve government and other stakeholders in development planning and decision-making, with establishment of clear roles and responsibilities for all stakeholders. Thus, co-management is neither a top-down approach, nor a laissez-faire strategy, for development (Ykhanbai 2011, cited in Vernooy 2011).

Adopting a co-management approach to wildlife and environmental conservation is a significant step in China. As elsewhere, the human dimensions of conservation have generally been overlooked, even though it is social matters directly and indirectly related to specific conservation goals that most often lead to a project's success or failure; biological considerations or technical interventions alone rarely achieve desired outcomes. In implementing this new approach, however, there is opportunity to help shape and change patterns of behaviour - and to engage a fuller cross section of society in partnership for wildlife conservation. If this approach is not fully realized, much opportunity will be lost, viz. partnerships for conservation, cost-effectiveness, support for anti-poaching, regular provision of wildlife data through observations and provision of ancillary information that can help guide conservation management decisions. It is crucial therefore to further research and trial, and to lend political support to, community co-management of natural resources.

The experiences that have been developed with and by Tibetan pastoral communities in the Yangtze River headwaters, over more than a decade, have been instrumental for the collaborative work now endorsed, at least in principle, by national authorities. More people-centred approaches to wildlife and nature conservation should be encouraged, as it is only through fair and open processes of negotiation and consensus-building that long-term sustainable, viable options for conservation will be developed. Multiple actor levels must be integrated into a single systems thinking, incorporating multiple sectors and interest groups. An integration of interests must take place. Not least amongst these stakeholders should be the people who have long lived on the land, the herders themselves. As has been presented herein, pastoral people are now proving afresh that they can still play a dynamic role in the maintenance of ecological services and biodiversity conservation, simultaneously with their continued development as communities familiar with the land and its resources, and who also search for an integration of socio-economic opportunities and sustainability. 


\section{Competing interests}

The author declares that he has no competing interests.

\section{Authors'contributions}

MF designed and led nearly all aspects of the community-based conservation and sustainable development programme carried out by Plateau Perspectives since 1998, as has been described in this paper. Through this process, he has learned much about the complex yet effective approach to natural resource conservation that is "collaborative management." Based on this experience, MF drafted the manuscript and submitted it for peer review. All authors read and approved the final manuscript.

\section{Authors' information}

MF is the Director of Plateau Perspectives, an Honorary Research Fellow in the School of Anthropology and Conservation, University of Kent and an associate professor in Qinghai Normal University.

\section{Acknowledgements}

For reviewing early versions of this manuscript, special thanks are due to Jesse Montes, Du Fachun and Carol Kerven. For long-term partnership in the work described herein, I also give special thanks to Marion Torrance-Foggin, Jigme Rabden and Gongbo Tashi.

\section{Author details}

'Plateau Perspectives, 200 Walnut Ave, St Lambert, Quebec J4P 2T1, Canada. ${ }^{2}$ School of Anthropology and Conservation, University of Kent, Canterbury CT2 7NZ, UK. ${ }^{3}$ Qinghai Normal University, Xining 810008, People's Republic of China.

Received: 24 May 2012 Accepted: 28 June 2012

Published: 28 September 2012

\section{References}

Banks, T, Richard, C, \& Yan, Z (2003). Community-based grassland management in Western China: rationale, pilot project experience, and policy implications. Mountain Research and Development, 23(2), 132-140. doi:10.1659/0276-4741(2003)023[0132:CGMIWC]2.0.CO;2.

BirdLife International. (2012). Grus nigricollis. In IUCN Red List of Threatened Species. Version 2012.1. http://www.iucnredlist. org. Accessed 15 September 2012

Blumenthal, D, \& Jannink, JL (2000). A classification of collaborative management methods. Conservation Ecology, 4(2), 13. http://www.consecol.org/vol4/iss2/art13/.

Borrini-Feyerabend, G (1996). Collaborative management of protected areas: Tailoring the approach to the context. IUCN Social Policy Group. Gland: IUCN. http://www.iucn.org/themes/spg/Tailor/index.html.

Borrini-Feyerabend, G, Pimbert, M, Farvar, MT, Kothari, A, \& Renard, Y (2004). Sharing power: Learning by doing in comanagement of natural resources throughout the world. Cenesta: IIED and IUCN/CEESP/CMWG. Tehran.

Borrini-Feyerabend, G, Kothari, A, Oviedo, G, Bassi, M, Larsen, PB, Ferrari, MF, Pansky, D, \& Pathak, N (2004). Towards equity and enhanced conservation: Guidance on policy and practice for co-managed protected areas and community conserved areas. Best Practice Protected Area Guidelines Series No. 11. IUCN - The World Conservation Union. World Commission on Protected Areas (WCPA).

Breivik, I (2007). The political ecology of grassland conservation in Qinghai Province, China: Discourse, policies and the herders. MA thesis, Department of International Environment and Development Studies (NORAGRIC). Norway: Norwegian University of Life Sciences.

Chen, H, Shivakoti, G, Zhu, T, \& Maddox, D (2012). Livelihood sustainability and community based co-management of forest resources in China: changes and improvement. Environmental Management, 49(1), 219-228.

Cho, J (2011). Poverty alleviation through ecotourism in the three parallel rivers world heritage site, Yunnan China. MA thesis, East Asian Studies, Department of Culture Studies and Oriental Languages. Norway: University of Oslo.

Foggin, JM (2000). Biodiversity protection and the search for sustainability in Tibetan plateau grasslands. PhD dissertation, Department of Zoology. Tempe, Arizona, USA: Arizona State University.

Foggin, JM (2005a). Promoting biodiversity conservation and community development in the Sanjiangyuan region: Proceedings of a conservation planning meeting, with agreed priority action points. Conservation planning meeting cohosted by Plateau Perspectives, Upper Yangtze Organization, Government of Zhiduo County and Sanjiangyuan National Nature Reserve Management Bureau held in Yushu, China, Sep 30 - Oct 13, 2005. Xining: Plateau Perspectives.

Foggin, JM (2005b). Highland encounters: Building new partnerships for conservation and sustainable development in the Yangtze River headwaters, heart of the Tibetan Plateau. In I Velasquez, M Yashiro, S Yoshimura, \& I Ono (Eds.), Innovative communities: People-centred approaches to environmental management in the Asia-Pacific region (pp. 131-157). Tokyo: United Nations University Press.

Foggin, JM (2008). Depopulating the Tibetan grasslands: national policies and perspectives for the future of Tibetan herders in Qinghai Province, China. Mountain Research and Development, 28(1), 26-31. doi:10.1659/mrd.0972.

Foggin, JM (2011a). Tracking Tibet's snow leopards; local herders are central to protecting the snow leopard in the source area of the Yangtze River. China: Dialogue. http://www.chinadialogue.net/article/show/single/en/4615-SlideshowTibet-s-snow-leopards.

Foggin, JM (2011b). Rethinking 'ecological migration' and the value of cultural continuity-a response to Wang, Song, and Hu. AMBIO: A Journal of the Human Environment, 40, 100-101.

Foggin, JM, \& Bass, MH (2010). Mainstreaming environment into development: Collaborative land management in the Tibetan grasslands. China: LEAD International. http://www.lead.org/page/573. Accessed 9 July 2011. 
Foggin, JM, \& Torrance-Foggin, ME (2011). How can social and environmental services be provided for mobile Tibetan herders? Collaborative examples from Qinghai Province (1st ed., p. 21). China: Pastoralism: Research, Policy and Practice.

Foggin, PM, Torrance, ME, Dorje, D, Xuri, W, Foggin, JM, \& Torrance, J (2006). Assessment of the health status and risk factors of Kham Tibetan pastoralists in the alpine grasslands of the Tibetan Plateau. Social Sciences and Medicine, 63, 2512-2532. doi:10.1016/.socscimed.2006.06.018.

Goldstein, MC, \& Beall, CM (1990). Nomads of Western Tibet: The survival of a way of life. Berkeley: University of California Press.

Harris, RB (2008). Wildlife conservation in China: Preserving the habitat of China's wild west. Armonk: ME Sharpe.

Harris, RB (2009). Rangeland degradation on the Qinghai-Tibetan plateau: a review of the evidence of its magnitude and causes. Journal of Arid Environments, 74, 1-12.

Harris, RB, \& Leslie, D (2008). Bos mutus. In IUCN Red List of Threatened Species. Version 2011.2. http://www.iucnredlist.org. Accessed 15 May 2012.

Jackson, R, Mallon, D, McCarthy, T, Chundaway, R A, \& Habib, B (2008). Panthera uncia. In IUCN Red List of Threatened Species. Version 2011.2. http://www.iucnredlist.org. Accessed 15 May 2012.

Kothari, A (2008). Protected areas and people: the future of the past. Parks, 17(2), 23-34.

Lhamo, B, \& Tsering, P (2008). Sanjiangyuan National Nature Reserve, Suojia community co-management and biodiversity protection project plan. Xining. China: Sanjiangyuan National Nature Reserve and Plateau Perspectives. http://plateauperspectives.org/downloads/Project\%20plan.pdf.

Li, WJ, \& Han, NY (2001). Ecotourism management in China's nature reserves. AMBIO, 30(1), 62-63.

Liu, JY, Yue, TX, Ju, HB, Wang, Q, \& Li, XB (2005). Integrated Ecosystem Assessment of Western China. Beijing, China: Ministry of Science and Technology. http://www.maweb.org/en/SGA.WesternChina.aspx.

Liu, J, Harris, J, Zhao, L, Jiang, H, \& Qian, F (2011). Integrating community development with management of grasslands and wetlands at the Keerqin Nature Reserve, Inner Mongolia, China. In Conservation of flyway wetlands in East and West/ Central Asia. Proceedings of the Project Completion Workshop of the UNEP/GEF Siberian Crane Wetland Project, 14-15 October 2009, ed. C. Prentice. Harbin. China: Baraboo (Wisconsin), USA: International Crane Foundation.

Lynam, T, DeJong, W, Sheil, D, Kusumanto, T, \& Evans, K (2007). A review of tools for incorporating community knowledge, preferences, and values into decision making in natural resources management. Ecology and Society, 12(1), 5. http://www.ecologyandsociety.org/vol12/iss1/art5/.

Mallon, DP (2008). Pantholops hodgsonii. In IUCN Red List of Threatened Species. Version 2011.2. http://www. iucnredlist.org. Accessed 15 May 2012.

Miller, D (2000). Tough times for Tibetan nomads in western China: traditional nomadic pastoralism. Nomadic Peoples, 4(1), 83-109.

Nabavi, SAH (2009). Poverty and micro enterprise development. European Journal of Social Sciences, 9(1), 120-128.

Næss, MW (2004). Living with risk and uncertainty: The case of the nomadic pastoralists in the Aru Basin, Tibet. MA thesis, Department of Social Anthropology. Norway: University of Troms $\varnothing$.

Plateau Perspectives. (2011a). Snow leopard research and conservation: Trialing new forms of 'collaborative management' in the Sanjiangyuan National Nature Reserve. Field report. Xining. China: Plateau Perspectives.

Plateau Perspectives. (2011b). A new approach to biodiversity conservation: Community co-management in Tibetan grasslands. Project information brochure. (December 2011). Xining. Plateau Perspectives: China.

Qiu, J (2008). China: the third pole. Nature, 454, 393-396.

Reed, MS (2008). Stakeholder participation for environmental management: a literature review. Biological Conservation, $141,2417-2431$.

Ross, H, \& Powell, B (2008). Collaborative management: an option for water resources management in the Pacific? Australian Water Research Facility Policy Brief. Brisbane. Australia: International WaterCentre. http://www.watercentre.org/.

Schaller, GB (1998). Wildlife of the Tibetan steppe. Chicago: University of Chicago Press.

Schlick, K (2011). Biodiversity conservation governance on the Tibetan Plateau: Cross-scale linkages and bridging organizations. MSc thesis, School of Geography, Environment and Earth Sciences. New Zealand: Victoria University of Wellington.

Schmidt, SM (2006). Pastoral community organization, livelihoods and biodiversity conservation in Mongolia's Southern Gobi Region. In D. Bedunah, ED McArthur, \& M Fernandez-Gimenez (Eds.), Rangelands of Central Asia: Proceedings of the Conference on Transformations, Issues, and Future Challenges, 2004 January 27, in Salt Lake City, UT (pp. 18-29). U. S: Department of Agriculture, Forest Service, Rocky Mountain Research Station: USDA Forest Service Proceedings RMRS-P-39. Fort Collins, CO.

Shah, N (2002). Status and action plan for the Kiang (Equus kiang). In PD Moelhman (Ed.), Equids: zebras, asses and horses: Status survey and conservation action plan (pp. 72-81). Gland: IUCN/SSC Equid Specialist Group. IUCN.

Shah, N, St. Louis, A, Huibin, Z, Bleisch, W, van Gruissen, J Qureshi, Q (2008). Equus kiang. In IUCN Red List of Threatened Species. Version 2012.1. http://www.iucnredlist.org. Accessed 15 September 2012.

Sheehy, DP, Miller, D, \& Johnson, DA (2006). Transformation of traditional pastoral livestock systems on the Tibetan steppe. Sécheresse, 17, 142-151.

Shen, XL, Li, SZ, \& Lu, Z (2011). A new approach to conservation in western China. In J. Keeley \& Y. S. Zheng (Eds.), Green China: Chinese insights on environment and development. London: International Institute for Environment and Development.

Smith, RJ (2009). Let the locals lead. Nature, 462, 280-281.

TIES (The International Ecotourism Society). (2012). What is ecotourism? http://www.ecotourism.org/what-is-ecotourism. Accessed 15 May 2012.

Vernooy, R (2011). How Mongolian herders are transforming nomadic pastoralism. Solutions, 2(5), 82-87. http://www. thesolutionsjournal.com/node/983. Accessed 12 June 2012.

Wang, XH (2009). Ecological restoration in west China: problems and proposals. AMBIO, 38(3), 177-179.

Wang, XH, \& Fu, XF (2004). Sustainable management of alpine meadows on the Tibetan Plateau: problems overlooked and suggestions for change. AMBIO, 33(3), 169-171. 
Wang, SH, Heo, J, Yamada, N, \& Hwang, ST (2009). Comparison of ecotourism policies and implications for China's ecotourism development. Journal of China Tourism Research, 5, 259-272.

Wang, GY, Innes, JL, Wu, SW, Krzyzanowski, J, Yin, YY, Dai, SY, Zhang, XP, \& Liu, SH (2012). National park development in China: conservation or commercialization? AMBIO, 41, 247-261. doi:10.1007/s13280-011-0194-9.

Xin, H (2008). A green fervor sweeps the Qinghai-Tibetan Plateau. Science, 321, 633-635.

Xu, JC, Yang, Y, Li, Z, Tashi, N, Sharma, R, \& Fang, J (2008). Understanding land use, livelihoods, and health transitions among Tibetan nomads: a case from Gangga Township, Dingri County, Tibetan Autonomous Region of China. EcoHealth, 5(2), 104-114. doi:10.1007/s10393-008-0173-1.

Yang, QX (2011). Partnership for facilitating sustainable protected area management: A case study of Jiuzhaigou National Park in south-western China. MA thesis. New Zealand: Massey University.

Yao, TD, Thompson, LG, Musbrugger, V, Ma, YM, Zhang, F, Yang, XX, \& Joswiak, D (2011). Third pole environment. UNESCO-SCOPE-UNEP Policy Briefs Series 13. Paris, France: UNESCO TPE.

Yeh, E (2005). Green governmentality and pastoralism in western China: 'converting pastures to grasslands'. Nomadic Peoples, 9(1), 9-29.

Ykhanbai, H (Ed.). (2011). Co-management of natural resources in Mongolia: Ten years of experience. Ulaanbaatar: Admon Publishing House.

Ykhanbai, H, Enkhbat, B, Ulipkan, B, Vernooy, R, \& Graham, J (2004). Reversing grassland degradation and improving herders' livelihoods in the Altai Mountains of Mongolia. Mountain Research and Development, 24, 96-100.

doi:10.1186/2041-7136-2-17

Cite this article as: Foggin: Pastoralists and wildlife conservation in western China: collaborative management

within protected areas on the Tibetan Plateau. Pastoralism: Research, Policy and Practice 2012 2:17.

\section{Submit your manuscript to a SpringerOpen ${ }^{\circ}$ journal and benefit from:}

- Convenient online submission

- Rigorous peer review

- Immediate publication on acceptance

- Open access: articles freely available online

- High visibility within the field

- Retaining the copyright to your article

Submit your next manuscript at $\boldsymbol{~ s p r i n g e r o p e n . c o m ~}$ 